\title{
Phytochemical, Proximate and Nutrient Composition of Vernonia calvaona Hook (Asterecea): A Green-Leafy Vegetable in Nigeria
}

\author{
Igile G. O. ${ }^{1}$, Iwara I. A. ${ }^{1}$, Mgbeje B. I. A. ${ }^{1}$, Uboh F. E. ${ }^{1} \&$ Ebong P. E. ${ }^{1}$ \\ ${ }^{1}$ Department of Biochemistry, College of Medical Sciences, University of Calabar, Calabar, Nigeria \\ Correspondence: Igile G. O., Department of Biochemistry, College of Medical Sciences, University of Calabar, \\ Calabar, Nigeria. Tel: 234-802-279-0020. E-mail: goitech2000@yahoo.com
}

Received: August 2, 2013 Accepted: September 16, 2013 Online Published: September 23, 2013

doi:10.5539/jfr.v2n6p1

URL: http://dx.doi.org/10.5539/jfr.v2n6p1

\begin{abstract}
The leaf of Vernonia calvaona was analysed for its phytochemical, proximate, anti-nutrient, mineral elements and vitamin compositions using standard analytical procedures. Flavonoids $(7.07 \pm 0.43 \%)$ were the most dominant plant secondary compound, followed by steroidal saponins $(4.42 \pm 0.23 \%)$, phenolic compounds (3.19 $\pm 0.05 \%)$, and carotenoids $(1.62 \pm 0.11 \%)$. Alkaloids $(1.26 \pm 0.13 \%)$, and sesquiterpene lactones $(1.64 \pm 0.13 \%)$ were also present in the plant. The proximate analysis of the fresh leaf gave a carbohydrate content of $20.80 \pm$ $0.67 \mathrm{mg} / 100 \mathrm{~g}$, with a corresponding reducing sugar content of $8.56 \pm 0.06 \mathrm{mg} / 100 \mathrm{~g}$. The sample also gave a protein content of $19.80 \pm 0.61 \mathrm{mg} / 100 \mathrm{~g}$ and fat content of $4.17 \pm 0.15 \mathrm{mg} / 100 \mathrm{~g}$ respectively. The total fatty acid content of the plant was $3.57 \pm 0.52 \mathrm{mg} / 100 \mathrm{~g}$. Overall the green-leafy vegetable of Vernonia calvaona which is usually eaten raw and fresh contains a very balanced nutrient composition and provides a total metabolising energy value of $844.49 \pm 6.19 \mathrm{KJ} / 100 \mathrm{~g}$. The plant has a crude fibre content of $7.63 \pm 0.22 \mathrm{mg} / 100$ $\mathrm{g}$ and an ash content of $10.67 \pm 0.33 \mathrm{mg} / 100 \mathrm{~g}$ respectively. The anti-nutrient levels, including oxalates $(0.34 \pm$ $0.04 \mathrm{mg} / 100 \mathrm{~g})$, phytates $(0.94 \pm 0.04 \mathrm{mg} / 100 \mathrm{~g})$ and cyanates $(0.09 \pm 0.01 \mathrm{mg} / 100 \mathrm{~g})$ were low compared to many known vegetables. The leaf is rich in vitamins (Vit C $11.33 \pm 0.88$, Vit A $0.61 \pm 0.01$ and Vit E $0.99 \pm 0.13$ $\mathrm{mg} / 100 \mathrm{~g}$ ). The leaf is also rich in vitamins $\mathrm{B}_{1}, \mathrm{~B}_{2}, \mathrm{~B}_{6}$, niacin and folic acid. The mineral profile of the leaf sample is also impressive, and includes some key elements such as, $\mathrm{Fe}, \mathrm{Zn}, \mathrm{Ca}, \mathrm{Na}, \mathrm{K}, \mathrm{Mg}, \mathrm{P}$ and $\mathrm{Se}$. It may be concluded that the leaves of $V$. calvaona contribute to nutrient intake by the consuming populations in Nigeria and can serve as an antimalarial, antidiabetic, fertility agent, anti-cancer, anti-ulcer and cardioprotective agent.
\end{abstract}

Keywords: Vernonia calvaona, vitamins, mineral elements, secondary compounds

\section{Introduction}

Vernonia calvaona Hook (Astereaceae) is popularly known as "Ekeke leaf" among the indigenous people of the central senatorial district of Cross River State of Nigeria. It is a small shrub of less than $1 \mathrm{~m}$ tall with petiolate leaves of about $10.0 \mathrm{~mm}$ wide which serve as a green-leafy vegetable as well as being used for ethno-medical purposes in Nigeria and Cameroun. It is popularly eaten raw and fresh as a local delicacy with or without palm oil in pepper sauce. It serves as a component of traditional salad among the indigenous consumers. It may also be cooked in native soups and stew, and in the preparation of potatoes, yam and plantain porridge. Its consumption is based on the native belief that the plant as a whole cures heart diseases, blindness, diabetes, malaria, stomach ache and as an anti-helminthic agent. It is eaten to prevent constipation. Most people eat it fresh and raw because the vegetable imparts a sweet taste like sugar in the tongue after its consumption. It is less bitter than the sister plant (Vernonia amygdalina), and yet both plants are used for the same ethno-medicinal purposes. The plant is widely distributed in South Western Cameroun and South-Eastern part of Nigeria, just like its close relatives $V$. tenoreana, and $V$. amygdalina. These three species are morphologically similar in many respects, though they can be differentiated using some anatomical features such as the height and broadness of the leaves, as well as the intensity of bitter taste of plant. Of these three species V. calvaona is the shortest in height. On the other hand, $V$. amygdalina is the most bitter of the three, followed by $V$. tenoreana and the least bitter is $V$. calvaona. Nothing has been scientifically reported about $V$. calvaona, inspite of its rich phytochemical and nutrient composition which contributes significantly to the dietary nutrient intake by the consuming populations of Eastern Nigeria and South Western Cameroun. Its popular sister species (V. amygdalina and V. tenoreana) have been thoroughly investigated with respect to human nutrition, glycaemic effect, lipidemic effect, antimalarial, anthelminthic, 
anti-diabetic and antitumorigenic activities (Gyang et al., 2004; Ojiako \& Nwanjo, 2006; Igile et al., 1995; Ebong et al., 2008). Considerable attention had been focused on the pharmacodynamic properties of $V$. amygdalina especially its hypoglycaemic activities (Ogbuokiri et al., 1989; Akah \& Okafor, 1992). More recently, Abosi and Raseroka (2003) and Izevbigie et al. (2004) discussed antimalarial, anthelminthic and antitumorigenic properties of $V$. amygdalina. Ijeh and Ejike (2011) reviewed the work so far done on the medicinal potential of $V$. amygdalina and hope for the future on the usefulness of this plant for food and medicinal purposes. On the other hand, $V$. calvaona has received very little or no attention in this respect despite its close taxonomic relationship to $V$. amygdalina and its various and potential medicinal and dietary uses.

The importance of the nutritional quality of vegetables to Nigerians has resulted in increased demand for knowledge of the nutrient composition of vegetable foods. Green leafy vegetables are important components of the dietary regime of humans because they provide the necessary vitamin and mineral elements required for growth and maintenance of good health through all ages (Fasuyi, 2006). Green-leafy vegetable foods also contain antinutrients which reduce the bioavailability of important nutrients substances in foods (Akindahunsi \& Salawu, 2005; Binita \& Khetarpaul, 1997). Aleto and Adeogun (1995), reported that some antinutrients exhibit protective effects thus making them serve dual purposes. For instance, oxalates bind to calcium to form calcium oxalate crystals, which prevent the absorption and utilization of calcium by the body thereby causing diseases such as rickets and osteomalacia (Ladeji et al., 2004). The calcium crystals thus formed may also precipitate around renal tubules causing renal stones. On the other hand phytatic acid combines with some essential elements such as $\mathrm{Fe}, \mathrm{Ca}, \mathrm{Zn}$ and $\mathrm{P}$ to form insoluble salts called the phytates which are not absorbed by the body thus making the minerals non-bioavailable. Saponins are plant naturally occurring steroidal or triterpenoidal glycosides found in a wide variety of plants. Some are known to be poisonous to humans, causing cell lysis and hemolysis, teratogenesis, and post-partum hemorrhage when ingested orally or when injected into the blood stream (Igile et al., 1994; Applebaum et al., 1969).Tannins are water soluble phenolic compounds with the ability to precipitate proteins from aqueous solutions. They occur almost in all vascular plants. They combine with digestive enzymes thus making them unavailable for digestion (Agbara, 2003; Binita \& Khetapaul, 1997). Despite the fact that vegetables are widely consumed because of their accepted nutritional value, there is lack of sufficient information on the antinutritional factors in some of them, including $V$. calvaona. The present study was therefore undertaken to assess $V$. calvaona for its nutrient value and phytochemical composition, as well as to determine the level of antinutritional factors in the vegetable, with a view to advancing further research into its potential medicinal and pharmacological value to mankind.

\section{Materials and Methods}

\subsection{Source of Plant Material}

Vernonia calvaona (Ekeke) green-leafy vegetable was purchased from Assiga daily market in Yakurr LGA of Cross River State of Nigeria and quickly washed and stored under refrigeration. The plant sample was authenticated by Dr. Michael Eko, a Botanist in the University of Calabar, Nigeria, and a voucher specimen $(\mathrm{BCH} / \mathrm{VC} / 02)$ was deposited in the Herbarium of the Department of Biochemistry, University of Calabar, Nigeria.

\subsection{Sample Preparation}

Five hundred grammes $(500 \mathrm{~g})$ of the leaves were washed, cut into small pieces and air-dried at room temperature $\left(27 \pm 1.50{ }^{\circ} \mathrm{C}\right)$ for seven days for phytochemicals and anti-nutrients investigation and for the determination of mineral elements. The samples were ground into powder and stored each in an air tight bottle prior to use for analysis. Fresh leaf samples were used for the analysis of proximate composition and vitamins.

\subsection{Phytochemical Analysis}

Phytochemical analysis for tannins, phenolics, flavonoids, saponins, carotenoids, sesquiterpenoids, cardiac glycosides and alkaloids were carried out according to known and standard methods.

Tannins were estimated using the Folin-Denis spectrophotometric method (Pearson, 1976). Saponin content was determined using the method of Birk et al. (1963) as modified by Hudson and El Difrawi (1979). Flavonoids, alkaloids and sesquiterpene lactones were determined by ethyl acetate extraction and gravimetric measurement, the alkaline precipitation and gravimetric method, and the double extraction and gravimetric measurement, respectively as described by Harbone (1973).

\subsection{Analysis of Anti-Nutrients}

Total oxalate was determined according to the procedure of Day and Underwood (1986). Phytate content was determined using the method described by Reddy and Love (1999). Hydrocyanic acid content was determined 
using the alkaline titration method of AOAC (1990).

\subsection{Vitamin Analysis}

The composition of the water-insoluble vitamins, riboflavin, thiamine and pyridoxine, were determined by the method described by Scalar (2000), while ascorbic acid content was determined by the method of AOAC (1980). Vitamin A concentration was determined by the spectrophotometric method described by Pearson (1976).

\subsection{Mineral Analysis}

Minerals were determined after the dried powdered samples were first digested with nitric acid and perchloric acid and the filtered aliquots were used for the determination of sodium, potassium, calcium, magnesium, phosphorus, iron, copper, zinc, selenium, chromium, cobalt and manganese content. Potassium and sodium were determined by the Flame photometric method. Iron, copper, zinc, manganese, chromium, cobalt, selenium calcium and magnesium were determined by atomic absorption spectrophotometric method described by James (1995; AOAC, 1990).

\subsection{Proximate Analysis}

The analysis of the proximate composition of $V$. calvaona leaf was carried out using the official methods of analysis of the Association of Official Analytical Chemists (AOAC, 1984) and the FAO (1986).

\subsubsection{Determination of \% Moisture Content of $V$. calvaona}

The leaf sample was ground to a fine form and mixed well. Two grammes $(2 \mathrm{~g})$ of the sample was accurately weighed into a moisture dish (in triplicate). The sample was dried for $24 \mathrm{hrs}$ at $105^{\circ} \mathrm{C}$. After drying, the samples were removed from the oven (Memmert U.27) and placed in a desiccator to cool to constant weight. The percentage moisture content was calculated as follows:

$$
\% \text { Moisture }=\frac{(\mathrm{Y}-\mathrm{Z}) \times 100}{\mathrm{X}}
$$

where, $\mathrm{X}$ and $\mathrm{Y}$ are the sample weight and the weight of dish + sample, respectively prior to drying, and $\mathrm{Z}$ the weight of dish + sample after drying. $\mathrm{Y}-\mathrm{Z}$ is the loss in weight of sample after drying.

\subsubsection{Determination of \% Ash Content of $V$. calvaona}

Five grammes $(5 \mathrm{~g})$ of the leaf sample (fine form) was weighed into a porcelain dish that had previously been weighed. This was dried at $105^{\circ} \mathrm{C}$ for three hours in an oven. The dish with content was transferred to a muffle furnace (Heraeus M 110) and ignited at $500{ }^{\circ} \mathrm{C}$ until free from carbon (residue appears greyish-white). This was removed from the oven and the ash moistened with a few drops of water (to expose bits of unashed carbon). The ash was re-dried in the oven at $100{ }^{\circ} \mathrm{C}$ for 3 hours and re-ashed in the furnace at $500{ }^{\circ} \mathrm{C}$ for another one hour. This was removed from the muffle furnace, placed in a desiccator until it cooled, and was then weighed. The percentage ash was calculated as follows:

$$
\% \text { Ash }=\frac{(\mathrm{Y}-\mathrm{Z}) \times 100}{\mathrm{X}}
$$

where,

$\mathrm{X}=$ sample weight prior to drying

$\mathrm{Y}=$ weight of dish and contents after ashing

$\mathrm{Z}=$ weight of empty dish.

\subsubsection{Determination of \% Crude Protein of $V$. calvaona}

Two grammes ( $2 \mathrm{~g}$ ) of oven dried ground leaf sample was placed into $30 \mathrm{ml}$ Kjeldahl digestion flask (Gerhardt). Fifteen millilitres $(15 \mathrm{ml})$ of concentrated sulphuric acid and $1 \mathrm{~g}$ of catalyst mixture were added into the flask. The flask was gently heated on a digestion rack in a fume cupboard until a greenish clear solution appeared. After about 30 minutes when the digest had cleared, the flask was heated for another 30 minutes and allowed to cool. Ten millilitres $(10 \mathrm{ml})$ of distilled water was added to avoid caking. The sample was transferred to the Kjeldahl apparatus (Gerhardt). A $50 \mathrm{ml}$ receiver flask containing $5 \mathrm{ml}$ boric acid-indicator solution was placed under the condenser of the distillation apparatus so that the tip was about $2 \mathrm{~cm}$ inside the solution. To the digested sample in the apparatus was added $10 \mathrm{ml}$ of $40 \% \mathrm{NaOH}$ solution through funnel stopcock. Distillation commenced immediately by closing the steam by-pass and opening the inlet stopcock on the steam jet arm of the distillation apparatus. When the distillate reached the $35 \mathrm{ml}$ mark on the receiver flask, distillation was stopped 
by closing inlet stopcock first, then opening the steam by-pass. The condenser tip was rinsed with distilled water. The excess acid was titrated to first pink colour with $0.1 \mathrm{~N} \mathrm{NaOH}$. The percentage crude protein was calculated as follows:

$$
\% \text { Crude protein }=\frac{\text { Titre } \times 14.01 \times \text { Normality of the acid } \times 100 \times 6.25}{1000 \times \text { weight of samp }}
$$

Where, 6.25 is a general factor suitable for products in which the portion of specific protein is not well defined. $14.01 / 1000$ is a constant and titre is the volume after titration.

\subsubsection{Determination of \% Crude Fat (Ether Extract) Content of $V$. calvaona}

Five grammes $(5 \mathrm{~g})$ of the ground leaf sample was placed in a thimble lined with a circle of filter paper. The thimble with its contents was placed in a $50 \mathrm{ml}$ beaker and dried in an oven for 6 hours at $105{ }^{\circ} \mathrm{C}$. The thimble with its contents was transferred to a Soxhlet extractor. The beaker was rinsed three times with ethyl ether and emptied into the Soxhlet extraction flask. The sample contained in the thimble was extracted with ethyl ether for 6 to 8 hours at a condensation rate of $3-6$ drops per second. At the completion of the extraction, the fat extract was transferred from the extraction flask into a pre-weighed evaporating dish with several rinsing of ethyl ether. The evaporating dish was placed in a fumehood with the fan on, to evaporate the ethyl ether until no odour was detectable. The dish with its contents was dried in an oven for 30 minutes at $105{ }^{\circ} \mathrm{C}$, removed from the oven, cooled in a desiccator to constant weight and weighed. The percentage crude fat was calculated as follows:

$$
\% \text { Crude fat }(\text { ether extract })=\frac{\mathrm{W} 2-\mathrm{W} 1 \times 100}{S}
$$

where:

$\mathrm{W} 1=$ weight of empty evaporating dish

$\mathrm{W} 2=$ weight of evaporating dish + content after drying.

$\mathrm{S}=$ sample weight before drying

\subsubsection{Determination of \%Crude Fibre Content of $V$. calvaona}

Five grammes $(5 \mathrm{~g})$ of ground sample was weighed and placed in a 1 litre conical flask. A $150 \mathrm{ml}$ pre-heated $0.128 \mathrm{M} \mathrm{H}_{2} \mathrm{SO}_{4}$ was added and the content boiled for 30 minutes. The content was filtered through fluted funnel and the residue washed three times with hot water. To the digest was added $150 \mathrm{ml}$ preheated $0.15 \mathrm{M} \mathrm{KOH}$ and heated to boiling. Some drops of antifoaming agent (n-octanol) was added and the content boiled slowly for 30 minutes, filtered and the residue washed three times with hot water, followed by washing three times with acetone in Cold Extraction Unit (Tecator1615). The resulting residue was dried in the oven at $130{ }^{\circ} \mathrm{C}$ for $1 \mathrm{hr}$, cooled in a desiccators and weighed, and then ashed at $500{ }^{\circ} \mathrm{C}$ for 30 minutes, cooled in a desiccator and later weighed. The percentage crude fibre was calculated as follows:

where:

$$
\% \text { crude fibre }=\frac{\mathrm{W} 2-\mathrm{W} 1 \times 100}{\mathrm{~W} 1}
$$

W1 = Sample weight before drying

$\mathrm{W} 2=$ Weight of residue after drying

$\mathrm{W} 3=$ Weight of residue after ashing

\subsubsection{Determination of Nitrogen-Free Extract Content of $V$. calvaona}

The nitrogen-free extract of leaf sample was determined by summing up the percentages of moisture, ash, crude protein, fat (ether extract) and crude fibre, and subtracting from 100 (Mcdonald et al., 1973). The difference in value was designated the nitrogen-free extract.

\subsubsection{Determination of Carbohydrate Content of $V$. calvaona}

The percentage carbohydrate content of the leaf sample was determined by summing up the percentages of moisture, ash, crude protein, fat (ether extract) and subtracting from 100 (Mcdonald et al., 1973). The difference in value was taken as the percentage total carbohydrate content of the leaf sample. The total carbohydrate of the leaf sample is contained in two fractions, the crude fibre and the nitrogen-free extract. 


\subsubsection{Energy Value}

This was calculated in $(\mathrm{KJ} / 100 \mathrm{~g})$ using the equation: $[(37 \mathrm{x}$ fat $)+(17 \mathrm{x}$ carbohydrate $)+(17 \mathrm{x}$ protein $)$.

\subsection{Statistical Analysis}

All determinations were done in triplicates and data were expressed as Mean $\pm \mathrm{SEM}$. These data were subjected to analysis of variance (ANOVA).

\section{Results}

The results of the phytochemical composition, proximate analysis, anti-nutrients, mineral elements and vitamin composition of the vegetable sample are shown in Tables 1-5.

\subsection{Phytochemical Composition}

Table 1 shows the types and quantities of secondary compounds of metabolism present in the leaf sample analyzed. Flavonoids were shown to be present in appreciable amounts, followed by phenolic compounds and saponins. This suggests that $V$. calvaona is a strongly antioxidative plant.

Table 1. Phytochemical composition of Vernonia calvaona leaves (\% W/W DMB)

\begin{tabular}{lll}
\hline Constituent & Mean & SEM \\
\hline Tannins & 0.67 & \pm 0.03 \\
Flavonoids & 7.07 & \pm 0.43 \\
Alkaloids & 1.26 & \pm 0.13 \\
Sesquiterpene lactones & 1.64 & \pm 0.13 \\
Phenolic Compounds & 3.19 & \pm 0.05 \\
Steroidal Saponins & 4.42 & \pm 0.23 \\
Cardiac glycosides & 1.40 & \pm 0.17 \\
Carotenoids & 1.62 & \pm 0.11 \\
\hline
\end{tabular}

Values are mean \pm SEM of three determinations. $* \mathrm{DMB}=$ dry matter basis.

\subsection{Proximate Composition}

Table 2 shows the proximate composition of the leaf sample. The carbohydrate, protein and moisture content occured in appreciable amounts, suggesting that the leaf is a food material. The fibre and ash contents were also high and suggests the high nutritive value of $V$. calvaona.

Table 2. Proximate composition of Fresh leaves of Vernonia calvaona (mg/100 g)

\begin{tabular}{lll}
\hline Constituent & Mean & SEM \\
\hline Total Protein & 19.80 & \pm 0.61 \\
Total Fat & 4.17 & \pm 0.15 \\
Total Fatty acid content & 3.57 & \pm 0.52 \\
Carbohydrate & 20.80 & \pm 0.67 \\
Reducing Sugar & 8.56 & \pm 0.06 \\
Crude Fibre & 7.63 & \pm 0.22 \\
Ash Content & 10.67 & \pm 0.33 \\
Moisture content & 37.67 & \pm 0.33 \\
Energy (KJ/100g) & 844.49 & \pm 6.19 \\
\hline
\end{tabular}

Values are mean \pm SEM of three determinations.

\subsection{Anti-Nutrient Composition}

Table 3 shows the anti-nutrient composition of the leaf sample. All the three major anti-nutrients (oxalates, phytates and cyanates) gave low and non-toxic values with respect to known vegetables in human nutrition. 
Table 3. Antinutrient composition of fresh Leaves of Vernonia calvaona (mg/100 g)

\begin{tabular}{lll}
\hline Constituent & Mean & SEM \\
\hline Oxalates & 0.34 & \pm 0.04 \\
Phytates & 0.94 & \pm 0.04 \\
Cyanates & 0.09 & \pm 0.01 \\
\hline
\end{tabular}

Values are mean \pm SEM of three determinations.

\subsection{Mineral Profile}

The mineral composition of the plant sample is presented in Table 4. Iron, sodium, potassium and calcium were present in appreciable quantities. Generally, the plant is rich in vital mineral elements, confirming its use as a multi-purpose plant in nutrition and ethno-medicine.

Table 4. Mineral Composition of fresh leaves of Vernonia calvaona (\%W/W DMB)

\begin{tabular}{lll}
\hline Constituent & Mean & SEM \\
\hline $\mathrm{Fe}$ & 1.11 & \pm 0.07 \\
$\mathrm{Zn}$ & 0.54 & \pm 0.01 \\
$\mathrm{Co}$ & 0.40 & \pm 0.01 \\
$\mathrm{Cu}$ & 0.39 & \pm 0.03 \\
$\mathrm{Cr}$ & 0.63 & \pm 0.05 \\
$\mathrm{Na}$ & 1.08 & \pm 0.09 \\
$\mathrm{Mg}$ & 0.85 & \pm 0.07 \\
$\mathrm{Mn}$ & 0.25 & \pm 0.08 \\
$\mathrm{~K}$ & 2.46 & \pm 0.12 \\
$\mathrm{Ca}$ & 1.04 & \pm 0.22 \\
$\mathrm{P}$ & 0.68 & \pm 0.02 \\
$\mathrm{Se}$ & 0.06 & \pm 0.01 \\
\hline
\end{tabular}

Values are mean \pm SEM of three determinations.

\subsection{Vitamin Composition}

Table 5 shows the results of the vitamin composition of the leaf sample of $V$. calvaona. Vitamin $\mathrm{C}$ occurred highest followed by vitamins $\mathrm{E}, \mathrm{B}_{1}$ and $\mathrm{A}$ respectively. The presence of vitamins $\mathrm{A}, \mathrm{C}$ and $\mathrm{E}$ supports the potential value of this vegetable in anti-oxidation function.

Table 5. Vitamin Composition of fresh leaves of Vernonia calvaona $(\mathrm{mg} / 100 \mathrm{~g})$

\begin{tabular}{lll}
\hline Constituent & Mean & SEM \\
\hline Vitamin C & 11.33 & \pm 0.88 \\
Vitamin A & 0.61 & \pm 0.01 \\
Vitamin E & 0.99 & \pm 0.13 \\
Vitamin $_{1}$ & 0.94 & \pm 0.03 \\
Vitamin $_{1}$ & 0.16 & \pm 0.01 \\
Vitamin $\mathrm{B}_{6}$ & 0.56 & \pm 0.33 \\
Folic Acid & 0.26 & \pm 0.05 \\
Niacin & 0.34 & \pm 0.02 \\
\hline
\end{tabular}

Values are mean \pm SEM of three determinations. 


\section{Discussion}

\subsection{Phytochemicals}

The presence of flavonoids in appreciable amount $(7.07 \pm 0.43 \%)$, inferred that the vegetable has the biological functions such as anti-oxidation, and protection against allergies, inflammation, free radical, platelet aggregation, microbes, ulcers, hepatoxins, viruses and tumour (Okwu, 2004; Farquar, 1996). Flavonoids are potent water soluble antioxidants and free radical scavengers which prevent oxidative cell damage, and have strong anticancer and anti-ulcer activity and protection against the different levels of carcinogenesis (Okwu, 2004). Steroidal saponin content of $4.42 \pm 0.23 \%$ suggests the usefulness of the vegetable as a potential fertility agent. The saponin level is however low, when compared with the results from other works (Umaru et al., 2007; Ekop, 2007; Nkafamiya et al., 2007; Nkafamiya et al., 2010). Steroidal saponins at low levels $<10 \%$ are said to be safe and non-toxic. Saponins are glycosides containing polycyclic aglycone moiety of either C27 steroid or C30 triterpenoids attached to a carbohydrate sugar. High Saponin levels have been associated with gastroenteritsis, manifested by diarrhea and dysentery (Awe \& Sodipo, 2001). The presence of appreciable amounts of sesquiterpene lactones $(1.64 \pm 0.13 \%)$, and carotenoids $(1.62 \pm 0.11 \%)$, suggests that the plant may be useful as an anticancer and anti-ulcer agent, a claim that seem to support the traditional use the leaves for ethno-medical purposes.

Alkaloids were present in appreciable amount $(1.26 \pm 0.13 \%)$. Alkaloids are one of the most efficient therapeutically significant bioactive substances in plants. Pure isolated alkaloids and the synthetic derivatives are used as basic medicinal agents because of their analgesic, antispasmodic and bactericidal properties (Stray, 1998).

The low tannin $(0.67 \pm 0.03 \%)$ content in the vegetable implies that the leaf has little or no astringent properties. Tannins quicken the healing of wounds and inflamed mucous membranes (Farquar, 1996). Tannins are water soluble phenolic compounds which precipitate proteins from aqueous solution. They occur in all vascular plants. Tannins bind to proteins making them bio-unavailable (Bagepallis et al., 1993; Aleto, 1993; Sotel et al., 1995). The value in this vegetable is low compared with the findings from other plants (Chinma \& Igyor 2007; Ekop, 2007; Abidemi et al., 2009; Amoo et al., 2009; Nkafamiya et al., 2007).

\subsection{Proximate Composition}

The carbohydrate content was high $(20.80 \pm 0.67 \%)$ suggesting that the vegetable can serve as food. The monosaccharide or disaccharide composition of the carbohydrate may be responsible for the after-sweet-taste of the leaf. The moisture content was also high $(37.67 \pm 0.33 \%)$ indicating that the vegetable is susceptible to spoilage. The high ash content $(10.67 \pm 0.33 \%)$ is an indication of the level of inorganic elements such as calcium, zinc, magnesium, copper, and potassium in the vegetable.

The protein content was also high $(19.80 \pm 0.61 \%)$ and readily available as a macronutrient. Protein is an essential component of human diet needed for the replacement of tissues and for the supply of energy and adequate amount of required amino acids. Protein deficiency causes growth retardation, muscle wasting, oedema, abnormal swelling of the belly and collection of fluids in the body of children (Mounts, 2000). The crude fibre content $(7.63 \pm 0.22 \%)$ was high and may aid digestion, absorption of water from the body and bulk stool. Fibre softens stool and therefore, prevents constipation (Ayoola \& Adeyeye, 2009). The vegetable may therefore be very useful in the control of body weight, blood cholesterol and protection against colon cancer. The fat content $(4.17 \pm 0.15 \%)$ of the vegetable was low, and it can therefore be recommended as part of weight reducing diets. Low fat foods are said to reduce the level of cholesterol and obesity (Gordon \& Kessel, 2002). The low fat content correlates directly with the low total fatty acid content $(3.57 \pm 0.52 \mathrm{mg} / 100 \mathrm{~g})$ in the plant. The metabolising energy content of $V$. calvaona was calculated to be $844.49 \pm 6.19 \mathrm{KJ}$.

\subsection{Mineral Composition}

Of the minerals analyzed in the vegetable, potassium was the most abundant $(2.46 \pm 0.12 \mathrm{mg} / 100 \mathrm{~g})$ element, and this is in agreement with many reports that potassium is the most abundant mineral in Nigerian agricultural products (Afolabi et al., 1995). Potassium helps to maintain body weight and regulate water and electrolyte balance in the blood and tissues (National Research Council [NRC], 1989). The calcium content was determined to be $1.04 \pm 0.22 \mathrm{mg} / 100 \mathrm{~g}$. Calcium helps in the regulation of muscle contraction required by children, infants and foetuses for bones and teeth development (Margaret \& Vickery, 1997). The concentration of sodium in the sample was also low $(1.08 \pm 0.09 \mathrm{mg} / 100 \mathrm{~g})$, and supports the claim by the natives that the vegetable is useful in the treatment of heart related diseases. Excess sodium consumption leads to hypertension (NRC, 1989). The phosphorus content of the vegetable was $0.68 \pm 0.06 \mathrm{mg} / 100 \mathrm{~g}$. This figure is lower than that reported on other 
vegetables. Phosphorus plays a vital role in normal kidney functioning and transfer of nerve impulse. The concentration of zinc in the vegetable was given as $0.54 \pm 0.01 \mathrm{mg} / 100 \mathrm{~g}$. Zinc is said to be an essential trace element for protein and nucleic acid synthesis and normal body development (Melaku, 2005). Zinc also stimulates the activity of vitamins, and the formation of red and white blood cells (Claude \& Paule, 1979). Zinc plays a role in improving male fertility. The iron content of the vegetable was given as $1.11 \pm 0.07 \mathrm{mg} / 100 \mathrm{~g}$, and compares favourably with other vegetables. Iron is said to be an important element in the diet of pregnant women, nursing mothers, infants, convalescing patients and the elderly to prevent anaemia and other related diseases (Oluyemi et al., 2006). The magnesium content of the leaf was found to be $0.85 \pm 0.07 \mathrm{mg} / 100 \mathrm{~g}$. Magnesium plays fundamental roles in most reactions involving phosphate transfer. It is believed to be essential in the structural stability of nucleic acids. It plays a significant role in the intestinal absorption of electrolyte in the body. Its deficiency in man includes severe diarrhoea and persistent migraines (Appel, 1999). Cobalt occurred at a concentration of $0.40 \pm 0.01 \mathrm{mg} / 100 \mathrm{~g}$ in this plant, and this value is well below the concentration that is said to be critical $(1.5-5.0 \mathrm{mg} / 100 \mathrm{~g})$ in plant materials (Miroslav \& Vladimir, 1999). Cobalt plays an important role as an activating ion in some enzyme reactions (McDonald et al., 1995). The concentration of manganese in the plant sample was determined to be $0.25 \pm 0.08 \mathrm{mg} / 100 \mathrm{~g}$. This compared closely to that of Nuclea latifolia $0.21 \mathrm{mg} / 100 \mathrm{~g}$ (Hassan et al., 2004). Consumption of manganese-containing foods is believed to support the immune system. Manganese regulates blood sugar levels, the production of energy and cell reproduction. Deficiency in manganese may result in birth defects if an expectant mother does not get enough of this important element (Anhwange et al., 2004).

\subsection{Vitamin Composirion}

The vitamin profile of $V$. calvaona is shown in Table 5. Vitamin C was the most abundant element $(11.33 \pm 0.88$ $\mathrm{mg} / 100 \mathrm{~g})$ followed by Vitamin E $(0.99 \pm 0.13 \mathrm{mg} / 100 \mathrm{~g})$, Vitamin $\mathrm{B}_{1}(0.94 \pm 0.03 \mathrm{mg} / 100 \mathrm{~g})$, Vitamin A $(0.61$ $\pm 0.01 \mathrm{mg} / 100 \mathrm{~g})$ and Vitamin $\mathrm{B}_{6}(0.56 \pm 0.33 \mathrm{mg} / 100 \mathrm{~g})$, in that order. Vitamins A promotes growth, resistance to diseases and delays ageing. It also promotes the health of the eyes, skin, nails and hair (Claude \& Paule, 1979). Vitamin $\mathrm{B}_{2}$ carries oxygen to the cells, while Vitamin $\mathrm{B}_{6}$ promotes the metabolism of protides and non-saturated fatty acids. Vitamin $\mathrm{C}$ (ascorbic acid) promotes the health of teeth and gums, lungs and bronchia, and joints. Vitamin C also aids the purification o blood. Deficiency in ascorbic acid is associated with pains in the joints and defects in skeletal calcification, anaemia, manifestation of scurvy, and haemorrhage from the mucous membranes of the mouth and gastro intestinal tract (Hunt et al., 1980). The presence of ascorbic acid in the vegetable sample suggests that its consumption and use in herbal medicine can prevent against common cold and other diseases like prostate cancer (Okwu, 2004). Folic acid was determined to be $0.26 \pm 0.05 \mathrm{mg} / 100 \mathrm{~g}$ and it is essential in preventing birth defects. There is evidence that folic acid may prevent heart disease in both men and women of over 50 years of age. Niacin or nicotinamide is a coenzyme, which is involved in many biochemical processes including the detoxification of foreign compounds in the body (Njoku \& Akumefula, 2007).

\subsection{Anti-Nutrients}

Antinutritive factors limit the use of many plants for food because they elicit deleterious effects in both man and animals (Kubmarawa et al., 2008). Fortunately, the levels of anti-nutrients in this plant were found to be low compared to other vegetables in Nigeria (Agbaire et al., 2012). Oxalate content $(0.34 \pm 0.04 \mathrm{mg} / 100 \mathrm{~g})$ found in this study was low and is below the established toxic level. Oxalate tends to render calcium unavailable by binding to plasma calcium ion to form complexes (Al-Rais et al., 1971; Ladeji, 2004, Nkafamiya et al., 2006). The insoluble calcium oxalate complex may precipitate around soft tissues like the kidney, causing kidney stones (Oke, 1969). The phytate value recorded was low $(0.94 \pm 0.04 \mathrm{mg} / 100 \mathrm{~g})$ and non-toxic. According to Oke (1969) a phytate diet of 1-6\% over a long period of time decreases the bioavailability of mineral elements in mono gastric animals. Phytic acid is a strong chelator, forming protein and mineral-phytic acid complexes thereby decreasing protein and mineral bioavailability (Fasusi et al., 2003; Erdman, 1979). Phytate is associated with nutritional diseases such as rickets in children and osteomalacia in adult humans respectively. The cyanate level in the vegetable sample was also found to be low $(0.09 \pm 0.01 \mathrm{mg} / 100 \mathrm{~g})$ and non-toxic to humans and animals. It has been established that excess cyanate in the body inhibits the cytochrome oxidase. This may stop ATP formation and the release of inorganic phosphate to body tissues. Consequently, the body suffers energy deprivation and subsequent death. High level of HCN has been implicated in cerebral damage and lethargy in man and animal.

\section{Conclusion}

This study has shown the proximate, phytochemical, mineral and vitamin compositions of Vernonia calvaona as a balanced and rich source of macro- and micronutrients. The phytochemical profile shows the potential 
medicinal usefulness of the plant as an agent capable of ameliorating a myriad of diseases, including diabetes, malarial and cardiovascular problems. The leaf can be seen as a potential source of useful items for food and drugs formulation. Further research work is ongoing to confirm some of the ethno-pharmacological claims on Vernonia calvaona.

\section{References}

Abidemi, T. A., Adebayo, O. J., Idowu, O., \& Agbotoba, M. O. (2009). Nutrient content and anti-nutritional factors in shea butter (Butryospermum parkii) leaves. Afr. J. Biotechnol, 8(21), 5888-5890.

Abosi, O. A., \& Raseroka, B. H. (2003). In vivo antimalarial activity of Vernonia amygdalina. British Journal Biomedical Science, 60(2), 89-91.

Afolabi, G., Oluwade, A., \& Tunde, O. (1995). Estimation of Proximate and Mineral Composition of Some Tropical Crops. African Agricultural Journal, 21, 103.

Agbaire, P. O. (2012). Levels of anti-nutritional factors in some common leafy edible vegetables of southern Nigeria. African Journal of Food Science and Technology, 3(4), 99-101.

Agbara, A. E. (2003). Tannin content of Dioscorea bulbufera. J. Chem. Soc. Niger., 28, 55-56.

Akah, P. A., \& Okafor, C. I. (1992). Hypoglycaemic effect of Vernonia amygdalina Del. Inexperimental rabbits. Plant Medical Research, 1, 6-10.

Akindahunsi, A. A., \& Salawu, S. O. (2005). Phytochemical screening of nutrients and antinutrient composition of selected tropical green leafy vegetables. Afr. J. Biotehcnol., 4(6), 497-501.

Aleto, V. A. (1993). Allelochemical in plant food and feeding stuffs. Nutritional biochemical and physiopathological aspect in animal production. Vet. Hum. Toxicol, 35, 57-67.

Aleto, V. A ., \& Adeogun, O. A. (1995). Nutrients and antinutrients components of some tropical leafy vegetables. Food Chem, 54(4), 375-379. http://dx.doi.org/10.1016/0308-8146(95)99830-S

Al-Rais, A. H., Myers, S. A., \& Watson, O. (1971). The isolation and properties of oxalate crystals from plate. Ann. Botany, 35, 1213.

Amoo, I. A., Aasie, V. N., \& Kolawole, O. O. (2009). Proximate Composition, Nutritional valuable Minerals, protein. Functional Properties and Anti-Nutrient contents of Mucuna Preta, Mucuna Ghana and Mucuna Veracruz Mottle. Pak. J. Nutr, 8(8),1204-1208.

Anhwange, B. A., Ajibola, V. O., \& Oniye, S. J. (2004). Chemical Studies of the Seeds of Moringaoleifera and Deuterium microcarpum. Journal of Biological Sciences, 4(6), 711-715. http://dx.doi.org/10.3923/jbs.2004.711.715

AOAC. (1980). Official Methods of Analysis (14th ed.). Association of Official Analytical Chemists, Washington D.C.

AOAC. (1984). Official Methods of Analysis (14th ed.). Association of official Analytical Chemists.

AOAC. (1990). Official methods of analysis (15th ed.). Washington D.C USA. Association of Official Analytical Chemists inch. 400 - 2200Wilson Boalevard, Arlinton Virginia USA, 2, 910-928. http://dx.doi.org/10.3923/pjn.2009.1204.1208

AOAC. (2005). Official Method of Analysis (18th ed.). Association of Official Analytical Chemists Washington D.C. p. 106.

Appel, L. J. (1999). Nonpharmacologic Therapies that Reduce Blood Pressure. A fresh Perspective. Clin.Cardiol, 1111-1115.

Applebaum, S. W., Marfo, S., \& Birk, Y. (1969). Saponins as possible factors of resistance of legume seeds to the attack of insects. J. Agric. Food Chem, 17, 618-620. http://dx.doi.org/10.1021/jf60163a020

Awe, I. S., \& Sodipo, O. A. (2001). Purification of saponins of root of Blighia Sapida Niger. J. Biochem. Mol. Biol, 16(3), 201-204.

Ayoola, P. B., \& Adeyeye, A. (2009). Proximate Analysis and Nutrient Evaluation of Some Nigerian Pawpaw Seeds Varieties. Science Focus, 14(4), 554-558.

Bagepallis, S., Narasinga, R., \& Tatinemi, P. (1993). Tannin contents of foods commonly consumed in India and Its influence on ionisable iron. J. Sci. Food Agric, 33, 89-96.

Binita, R., \& Khetarpaul, N. (1997). Probiotic fermentation: Effect on antinutrients and digestability of starch 
and protein of indigenous developed food mixture. J. Nutr. Health, 139-147.

Birk, Y., Bondi, A., Gestetner, B., \& Ishaya, I. A. (1963). Thermostable hemolytic factor in Soybeans. Nature 197, 1089-1096. http://dx.doi.org/10.1038/1971089a0

Chinma, C. E., \& Igyor, M. A. (2007). Micronutrients and anti-nutritional contents of selected tropical vegetables grown in South East, Nigeria. Nigeria Food Journal, 25(1), 111-116.

Claude, B., \& Paule, S. (1979). The Manual of Natural Living (1st ed.). Biddles Ltd., Guildford, Surrey, pp. 98-101.

Day, R. A., \& Underwood, A. L. (1986). Quantitative Analysis (5th ed.), Prentice-Hall publication. p. 701.

Ebong, P. E., Atangwho, J. I., Eyong, E. U., \& Egbung, G. E. (2008). The Anti-diabetic efficacy of combined extracts from two continental plants: Azadirachta indica (A. Juss) (Neem) and Vernonia amygdalina (Del.)(African Bitter leaf). American $J$ of Biochemistry and Biotechnology, 4(3), 239-244. http://dx.doi.org/10.3844/ajbbsp.2008.239.244

Ekop, A. S. (2007). Determination of Chemical Composition of Gnetum africanum (AFANG) seeds. Pakistan J Nutr, 6(1), 40-43. http://dx.doi.org/10.3923/pjn.2007.40.43

Erdman, J. N. (1979). Oily seed phytates. Nutritional implications. J. Am oil Chem. Soc (JOCS), 56, 736-741.

FAO. (1986). Manuals of food quality control. Food analysis: general techniques, additives, contaminants and composition. FAO Food and Nutrition Paper, 14(7), 203-232.

Farquar, J. N. (1996). Plant Sterols, their biological effects in human (pp. 101-105). Handbook of Lipids in Nutrition BOCA Rotan HL CRC Press.

Fasasi, O. S., Eleyinmi, A. F., Fasasi, A. R., \& Karim, O. R. (2006). Chemical properties of raw and processed breadfruit (treculia africana) seed flour. Afr. Crop Science Conference Proceedings, 6, 547-551.

Fasuyi, A. O. (2006). Nutritional potentials of some tropical vegetable meals. Chemical characterization and functional properties. Afr. J. Biotech, 5(1), 49-53.

Gordon, M. N., \& Kessel, M. (2002). Perspective in Nutrition (5th ed.) (pp. 257-281). Ohio, New York: McGraw Hill Company.

Gyang, S. S., Nyam, D. D., \& Sokomba, E. N. (2004). Hypoglycaemic activity of Vernonia amygdalina (chloroform extract) in normoglycaemic and alloxan- induced hyperglycaemic rats. Journal of Pharmacy and Bioresources, 1(1), 61-66.

Harborne, J. B. (1973). Phytochemical methods (p. 278). London: Chapman and Hall.

Hassan, L. G., \& Umar, K. J. (2004). Proximate and Mineral Composition of Seeds and Pulp of African Locust Bean (Parkiabiglobosa). Nigerian Journal of Basic and Applied Sciences, 13, 15-27.

Hudson, B. J., \& EI-Difrawi, E. A. (1979). The sapogenins of the seeds of four lupin species. J. Plant Food, 3, 181-186.

Hunt, S., Goff, J. L., \& Holbrook, J. (1980). Nutrition Principles and Chemical Principles (pp. 49-52). New York: John Wiley and Sons.

Igile, G. O., Fafunsho, M., Fasanmade, A., Burda, S., Jurzysta, M., \& Oleszek, W. (1994). Toxicity of Vernonia amygdalina leaves, extracts and purified saponins in mice. Proc. Eurp. Food Tox., 2, 394-399.

Igile, G. O., Oleszek, W., Jurzysta, M., Burda, S., \& Jurzysta, M. (1995). Nutritional assessment of Vernonia amygdalina leaves in growing mice. J. Agric. Food Chem., 43, 2162-2166. http://dx.doi.org/10.1021/jf00056a038

Ijeh, F. I., \& Ejike, C. E. C. C. (2011). Current perspectives on the medicinal potentials of Vernonia amygdalina Del. J. Medicinal Plants Research, 5(7), 1051-1061.

Izevbigie, E. B., Byrant, J. L., \& Walker, A. (2004). A novel natural inhibitor of extracellular signal-regulated kinases and human breast cancer cell growth. Exp. Biol. Med., 229, 163-169.

James, C. S. (1995). Analytical Chemistry of Food. New York: Chapman Hall. http://dx.doi.org/10.1007/978-1-4615-2165-5

Kubmarawa, D., Andenyand, I. F. H., \& Magomya, A. M. (2008). Amino Acid profile of two Non-conventional leafy vegetables: Sesamum and Balanites aegyptiaca. Afr. J. Biotechnol, 7(19), 3502-3504. 
Ladeji, O., Akin, C., \& Umaru, U. (2004). Level of antinutritional factors in vegetables commonly eaten in Nigeria. Afri. J. Nt. Sci, 7, 71-73.

Margaret, L., \& Vickery, B. (1997). Plant Products of Tropical Africa. Macmillan in College ed. London.

Melaku, U., Clive, E. W., \& Habtamon, F. (2005). Content of zinc, Iron, Calcium and Their Absorption Inhibitors in Ethiopia. Journal of Food Composition Analysis, 18, 803-817. http://dx.doi.org/10.1016/j.jfca.2004.09.008

McDonald, P., Edwards, R. A., \& Greenhalgh, J. F. D. (1973). Animal Nutrition. (pp. 2-5). Edinburgh: T \& A Constable Ltd.

McDonald, A., Edwards, R. A., Greenhulgh, F. D., \& Morgan, C. A. (1995). Animal Nutriton (pp. 101-122). London: Prentices Hall.

Miroslav, R., \& Vladimir, N. B. (1999). Practical Environmental Analysis. (pp. 284, 314 \& 357). UK: Royal Society of Chemistry.

Mounts, T. L. (1972). The Chemistry of Components (2nd ed.). Royal Society of Chemistry.

Njoku, P. C., \& Akumefula, M. I. (2007). Phytochemical and Nutrient Evaluation of Spondias mombin Leaves. Pak. J. Nutr., 6(6), 613-615. http://dx.doi.org/10.3923/pjn.2007.613.615

Nkafamiya, II., \& Manji, A. J. (2006). A study of cyanogenetic Glucoside contents of some edible Nuts and Seeds. J. Chem. Soc. Niger, 31(1 and 2), 12-14.

Nkafamiya, II., Modibbo, U. U., Mariji, A. J., \& Haggai, D. (2007). Nutrient content of seeds of some wild plants. Afr. J. Biotechnol, 6(14), 1665-1669.

Nkafamiya, II., Osemeabon, S. A., Modibbo, U. U., \& Aminu, A. (2010). Nutritional status of non-conventional leafy vegetables (Ficus asperifolia and Ficus Sycomorus. Afr. J. Biotechnol, 4(3), 104-108.

NRC. (1989). National Research Council Recommended Dietary Allowance, National Academy Press, Washington D. C.

Ogbuokiri, J. E., \& Ekpechi, D. L. (1989). Anti-hyperglycaemic activity of Vernonia amygdalina on healthy adult volunteers. Clinical Pharmacy and Herbal Medicine, 5(3), 18-21.

Ojiako, O. A., \& Nwanjo, H. U. (2006). Is Vernonia amygdalina hepatotoxic or hepatoprotective? Response from biochemical and toxicity studies in rats. African Journal of Biotechnology, 5(18), 1648-1651.

Oke, O. L. (1969). Chemical studies on the more commonly used vegetables in Nigeria. Afr. Sci. Ass., 11, 42-48.

Okwu, D. E. (2004). PhytochemicalS and Vitamin content of indigenous spicies of South Eastern Nigeria. $J$. Sustain Agric. Environ, 6, 30-34.

Oluyemi, E. A., Akilua, A. A., Adenuya, A. A., \& Adebayo, M. B. (2006). Mineral Contents of Some Commonly Consumed Nigerian Foods. Science Focus, 11(1), 153-157.

Pearson, D. (1976). The Chemical Analysis of Foods (7th ed.). Edingburg: Churchill Livingstone.

Reddy, M. B., \& Love, M. (1999). The impacts of food processing on the nutritional quality of vitamins and minerals. Adv. Exp. Med. Bio., 459, 99-106. http://dx.doi.org/10.1007/978-1-4615-4853-9_7

Scalar. (2000). Ln: Segregated flow analyzer for analytical process Laboratories, Netherland.

Sotelo, A. E., Contrerar, S., \& Flores, S. (1995). Nutritional value and content of antinutritional compounds and toxics in ten wild legumes of Yucatan peninsula. Plant Food Hum. Nutri, 47, 115-123. http://dx.doi.org/10.1007/BF01089260

Stray, F. (1998). The Natural Guide to Medicinal Herbs and Plants (pp. 12-16). London: Tiger Books International.

Umaru, H. A., Adamu, R., Dahiru, D., \& Nadro, M S. (2007). Levels of antinutritional factors in some wild edible fruits of Northern. Nigeria. Afr. J. Biotechnol, 6(16), 1935-1938.

\section{Copyrights}

Copyright for this article is retained by the author(s), with first publication rights granted to the journal.

This is an open-access article distributed under the terms and conditions of the Creative Commons Attribution license (http://creativecommons.org/licenses/by/3.0/). 